\title{
WORK CENTRALITY, GOALS AND PROFESSIONAL FULFILLMENT: INTERSECTIONS BETWEEN WORK AND CAREER
}

\author{
ALÉXIA O. R. MOURA ${ }^{1}$ \\ (D) https://orcid.org/0000-0002-3092-9481 \\ LÍGIA C. OLIVEIRA-SILVA \\ (iD) https://orcid.org/0000-0002-7487-9420
}

To cite this paper: Moura, A. O. R., \& Oliveira-Silva, L. C. (2019). Work centrality, goals and professional fulfillment: Intersections between work and career. Revista de Administração Mackenzie, 20(1). doi:10.1590/1678-6971/eRAMG190087

Submission: Apr. 30, 2018. Acceptance: July 23, 2018.

Universidade Federal de Uberlândia (UFU), Uberlândia, MG, Brazil.

\section{(cc) BY




\section{ABSTRACT}

Purpose: This study aimed to analyze the degree to which the meaning of work, specifically the work centrality dimension, and the types of achievement goal orientations at work, predict professional fulfillment. Originality/value: The main contribution is to provide background for the identification of antecedents of a concept yet narrowly studied, which is professional fulfillment, signaling how counselors and organizations may facilitate the greater achievement of what is most valued in a career. We evidence the need to consider work an important sphere of life and to invest efforts in self-development to attain professional fulfillment.

Design/methodology/approach: This is quantitative, survey-type research involving 140 people who have been working for at least 6 months. An online questionnaire was answered containing absolute and relative work centrality, achievement goal orientation at work and professional fulfillment scales, as well as socio-demographic questions. Data were analyzed using bivariate correlations and multiple regression analysis.

Findings: Significant relationships of prediction were found between work centrality and professional fulfillment, as well as between one of the types of goal orientation and professional fulfillment. The results support two of the three predicted hypotheses, in addition to converging with previous research on the positive impacts of work centrality and the mastery approach orientation.

\section{KEYWORDS}

Professional Fulfillment. Career. Goals. Achievement Goal Orientation. Work Centrality. 


\section{INTRODUCTION}

How does the meaning of work and goal achievement can contribute to professional fulfillment? In the current socioeconomic context, work has been more considered as a human development environment, in which an activity performed in an efficient and motivating way reflects the reach of one's potentials. Changes caused by globalization, constant technological advance and great competition lead individuals to planning their careers more and more, establishing professional goals and using suitable strategies to achieve them.

Career has gathered new meanings in recent years, mainly if we consider the definition by Greenhaus (1987) that the career involves the diversity of professional experiences that extends throughout an individual's life. New career conceptions have been gaining strength as of the 90s, enhancing the idea of self-management. The "boundaryless" career, for instance, suggests that the individual is responsible for their own development through bonds with various organizations, signaling the necessity of physical and psychological mobility (Arthur \& Rousseau, 1996). In a similar emphasis, Hall (1996) addresses the protean career, which must be guided by the individual, based on individually defined goals and focused on psychological success and personal values.

Thus, it is understandable that the contemporary career vision implies in the assumption that they represent events that are actively created and managed through conscious decisions and based on evidence (Inkson, Dries $\&$ Arnold, 2015). Career self-management, for Seibert et al. (2013), involves the establishment of career goals, the development, and implementation of career planning and strategies. In this regard, the search for professional fulfillment presents itself as an important issue, for it demands greater attention to career building and self-management strategies development. People also become more responsible for their own professional fulfillment, which in turn concerns to the individual's perception that they reached their career goals or that they are on the correct path to achieve them (OliveiraSilva, Porto, \& Arnold).

The meaning of work would influence the ways of labor activity, the individual flexibility and productivity, as it would affect the beliefs on what is legitimate and can be tolerated in work (MOW, 1987). Aside from being a source of income, work represents something that can provide fulfillment, social status, possibility to establish and maintain interpersonal contacts 
and, thus, have a more significant life. In view of the possible benefits from labor activity, it is not unusual that work occupies a central position in our lives, so as the concept of work centrality is related to the importance of work in people's lives (Kubo \& Gôuvea, 2012). For Schweitzer, Gonçalves, Tolfo, and Silva (2016), the perspective of work centrality involves the relation with behaviors and constructs linked to the work and the subject, being centrality the most important component of the meaning and significance of work by considering the main theoretical perspectives that approach it. Such centrality could lead the individual to invest more effort into reaching their professional goals and, consequently, to achieve a state of professional fulfillment. At the same time, the ways through which people search for different kinds of goals can influence certain results, as for example, performance. Therefore, it is believed that different attitudes toward goal achievement, as well as the relevance that people assign to work, can influence professional fulfillment in a distinctive way.

Thus, it is proposed in this study that the meaning of work, more specifically the centrality dimension, predicts professional fulfillment. Studies such as the ones from Aryee and Luk (1996) reinforce this relation since they evidence positive correlations between work centrality and career. Wrzesniewski (2001), in turn, provided initial empirical validation for a taxonomy of work meanings, consisting of work as work, as a career and as a vocation.

Complementarily, since professional fulfillment represents the reaching of career goals (Oliveira-Silva, 2015), it was intended to investigate how achievement goal orientations could also predict professional fulfillment. Achievement goal orientations refer to what kinds of motives lead people to reach goals, in other words, if they are preoccupied in acquiring competencies and self-development (mastery orientation) or in showing to others they are competent (performance orientation) (Elliot \& Dweck, 2005). Thus, the aim of this study consisted of analyzing to what degree work centrality and the kinds of achievement goal orientations predict professional fulfillment, understood as the achievement of the most important career goals.

It is hoped, this way, to contribute to a better comprehension on how professional fulfillment, such an aimed state by those who follow a career, can be affected by the meaning and importance of work in individuals' lives, as well as by the way they pursue their goals. This present study is also relevant in the sense of exploring professional fulfillment construct, which although it is very popular among workers, it is still scarcely analyzed in the Management area. The investigation of this concept is shown as important, 
since it provides data to organizations and workers so that the aspects that help foster professional fulfillment can be comprehended, enabling interventions.

\section{PROFESSIONAL FULFILLMENT}

According to Oliveira-Silva (2015), professional fulfillment involves the effort spent by the people to live in compliance with the career goals established for themselves. This way, the concept refers to the perception of having attained one's career goals or being on the right track for attaining these goals. (Oliveira-Silva, Porto, \& Arnold, in press). It is not considered as a static process, but rather dynamic; people's values and goals can change, and, consequently, the way they pursue their goals and the meaning of professional fulfillment also change (Oliveira-Silva, 2015). Maslach, Schaufeli, and Leiter (2001), whilst conceptualizing the burnout syndrome mention the work fulfillment issue, indicate that the decrease in personal fulfillment at work represents one of the burnout indicators. Yet, it is worth to mention that, in this context, fulfillment is treated as opposed to the one presented by Oliveira-Silva (2015), as for Maslach et al. (2001) the focus is on the absence of fulfillment, equivalent to the worker tendency to selfassess themselves in a negative way, to feel unhappy with themselves and unsatisfied with their professional development.

Concepts that can be associated with fulfillment in a career have been addressed for quite some time. According to Kuijpers, Schyns, and Scheerens (2006), for instance, "career actualization" is defined as the fulfillment of goals and personal values in a career. However, the concept of career actualization is more associated to career competencies (Kuijpers et al., 2006; Beheshtifar, 2011) than to goal achievement, which amplifies the distinctions between this concept and professional fulfillment. Additionally, career actualization also does not represent a theoretical model and measurement instrument, as it is proposed for professional fulfillment. There are studies in the literature that describe personal goals at work, but each one represents a distinctive model of goal contents, making it hard to deepen and replicate studies. The human values model by Schwartz et al. (2012), on the other hand, has received wide acceptance throughout the years all over the world. Its second-order bipolar dimensions were found and replicated by various studies (Elster \& Sagiv, 2015).

The theoretical model proposed by Oliveira-Silva (2015) presents two constitutional dimensions of the professional fulfillment concept: 1 . the 
importance and attainment of specific types of career goals; 2 . the progress evaluation toward goals. In this study, as a matter of parsimony and theoretical coherence, only the first dimension was addressed, since the research consisted in analyzing how the meaning of work, more specifically the dimension of centrality, and the types of achievement goal orientations at work relate with specific contents of career goals.

In relation to the first dimension, the content of career goals is rooted in personal values, described by Schwartz et al. (2012) as criteria or goals that transcend specific situations. In this dimension, it is investigated the importance and attainment of goal content, assessed through four factors compatible with the two bipolar value dimensions, or motivational types from Schwartz et al. (2012), which were adapted by Oliveira-Silva (2015) to express career goals. They are 1 . self-transcendence, 2 . self-enhancement, 3 . openness to change and 4. conservation. Self-enhancement refers to the search for success, pleasure, respect and career recognition; openness to change concerns the search for innovative and challenging experiences in career; self-transcendence refers to the concern in contributing to nature and people welfare in career, while conservation pertains to the concern in attending social demands, not disappointing people and following rules and hierarchies throughout the career.

Career goals based on values can be understood as more abstract ones, representing the nature of the results of work experiences intended to be achieved, not necessarily by specifying a work or position in particular (Oliveira-Silva, Porto, \& Arnold). Therefore, the four proposed factors as possible goal contents could be applied to various types of career, labor activities and/or labor bonds, which reinforce the model comprehensiveness. In short, career goals are understood as abstract, conceptual and founded on basic motives about people's aspirations in a career (Greenhaus et al., 2010).

In general, structuralization of professional fulfillment concept proposes that people fulfill themselves through attaining career goals based on motives, which, in turn, offers opportunities to satisfy individuals' implicit needs (Oliveira-Silva, 2015). The search for personal goals grounded on strong implicit motives is considered by Schultheiss et al. (2008) a sentimentally "hot" way to achieve goals since the success and failure involved in this search allow individuals to experiment intense motivational gratification when goals are well-succeed.

Since it is a relatively new concept in a national setting, there are still not many studies aimed at the investigation of professional fulfillment (Oliveira-Silva, Porto, \& Arnold), is scarcely studied in Management both 
nationally and internationally wide. Despite the lack of research, OliveiraSilva (2015) found evidence that professional fulfillment significantly relates to subjective well-being and flourishing at work. In other words, the more people perceive they reach what they value and show a positive progress evaluation in regard to their professional goal, the more they experiment life's general well-being and the more they flourish at work. These findings help corroborate the relationship between professional fulfillment and the meaning of work, as so with the centrality dimension.

According to Tolfo \& Piccinini (2007), a meaningful work relates to the search for a useful work that allows development, fulfillment, recognition and, consequently, self-fulfillment. By seeing work as a necessity to satisfy other needs, the worker searches meaning to what is done, to be useful, valued and therefore fulfilled. Hence, considering the intersections between work meaning and professional fulfillment, it is understood as plausible that the attainment of professional fulfillment would be a consequence of meaning-making and, more specifically, influenced by work centrality.

\section{MEANING OF WORK AND CENTRALITY}

Work is seen as important as it is a means of production in one's life, providing subsistence, creating existential meanings or contributing to structuralizing personality and identity (Borges \& Tamayo, 2001). The significance one assigns to work stems from a cognitive structure that impacts on perceptions, assessments, attributions and one's own behavior in labor activities (Bastos, Pinho, \& Costa, 1995). One of the most classic definition on the theme is from Morin (2004), who suggests that "the concept of 'work significance' can be defined as the meaning one assigns to work, one's representation of work and the importance that it has in one's lives." (p. 4).

To some authors, like MOW (Meaning of Work International Research Team, 1987), Bastos, Pinho, and Costa (1995) and Borges (1999), there is no difference between the terms meaning and significance, there being, however, preference to the use of the term "meaning". A recent Bendassoli et. al. (2015) review discuss that the theme is approached in literature from four terminological usages: 1 . only significance of work, 2 . only meaning of work, 3. both meaning and significance, and 4 . a wide and fragmented set of researches in which it cannot be identified as a single terminological preference. 
Aiming the meaning of work concept exploration, studies conducted by MOW (1987) during six years (1978-1984) eight countries pointed out that the general structure of the concept involves three great domains: work centrality, work societal regulations and work valued results and goals (Kubo, Gôuvea, \& Mantovani, 2013). Bendassoli et. al (2015) discuss that the significance process involves a significance object, which regarding work relates to its centrality and its role in individual development. Kubo et al. (2013) point out that work centrality is the most relevant aspect in the meaning of work construct composition, furthermore it tends to increase in times of economic difficulties and to decrease in times of relative prosperity (Ardichvili \& Kuchinke, 2009), which emphasizes the importance to analyze work centrality in the current times of economic crisis, mainly in the Brazilian scenario. In face of such evidence, it is justified that work centrality represents the meaning of work domain addressed in the present study.

Work centrality is defined as the importance that the individual assigns to work in comparison to other life spheres, such as leisure, family, and religion. Thus, a highly work-centered person has a parcel of identity assigned to work-related experiences (Borges \& Tamayo, 2001). First studies on work as a central interest in comparison to one's other life areas were conducted by Dubin (1956). After this moment, researchers turned their attention to work centrality and its boundaries in relation to other concepts. Kanungo (1982), for instance, distinguishes work involvement and centrality, stating that the first refers to the individual's current work context, while the second relates to work as a general concept.

The MOW (1987) investigations, previously mentioned, bring greater notoriety to the theme. They point out a variety of reasons to highlight work centrality, some of economic/instrumental order and others of intrinsic order, such as the sense of identity and satisfaction (Rios, 2015). According to Tolfo and Piccinini (2007), the complex construct of work centrality consists of two components. The first one is the absolute centrality of work, which measures the absolute work value in people's lives and identifies to what degree work is central to self-image. The second component would be the relative centrality of work, which measures the relation of work in comparison with other interests in people's lives.

A review by Kostek (2012) indicated that people with high levels of work centrality report high levels of life and work satisfaction, as well as perform their labor functions in a more satisfactory way than individuals with low levels of work centrality. Moreover, Kostek (2012) evidenced that people who value work as an important aspect in their lives enjoy more their 
respective jobs, remain longer in organizations, contribute beyond expectations in their functions, earn more money and present less negative psychological symptoms than those who do not value work as something important in their lives. Similarly, results found by Sharma (2017) indicate that the greater the work centrality, the lesser the interference of work in personal life, the greater the enhancement of personal/professional life, and the greater the global balance of professional life. Walia (2011), in turn, has also found a positive correlation between work centrality and work-life balance. Lastly, studies indicate that organizational citizenship behaviors, organizational commitment, and career satisfaction are also positively predicted by work centrality (Aryee \& Luk, 1996; Diefendorff et al., 2002). From these evidence, the following hypothesis is proposed:

H1: Work centrality positively and significantly predicts professional fulfillment.

\section{ACHIEVEMENT GOAL ORIENTATION}

When individuals want to reach a goal, they present different orientations or ways to attain it, in a way that these orientations will guide their attitudes, cognitions, and affections (Elliot \& Dweck, 2005). This premise integrates the Achievement Goal Orientation (AGO) theory, which represents one of the most active areas of research in what refers to motivation and goals and describes how different types of achievement goals can influence certain results (Oliveira-Silva \& Porto, 2016).

AGO includes the purpose of goal achievement (mastery or performance) and the patterns and criteria individuals can use to define their goals, being them self-referent or comparative. Mastery goals concern the belief in the effort that leads to success, focusing on the development of competencies, learning, task/work comprehension and self-referent patterns of enhancement. Thus, mastery goals present an interpersonal orientation. On the other hand, performance goals involve the preoccupation in standing out from others in tasks, exceed rules and receive personal recognition, being associated to the exhibition of competence in relation to others, so that the performance goals have an interpersonal orientation (Lee, McInerney, Liem, \& Ortiga, 2010).

Furthermore, achievement goal orientation might tend for competence acquisition or incompetence avoidance (Elliot \& Dweck, 2005). This way, approach and avoidance dimensions are considered for each orientation 
(mastery and performance). In mastery approach orientation, people behave focusing their own learning, competence development, and task/work comprehension. In mastery avoidance orientation, though, people avoid demonstrating they do not understand something or that they cannot master a task (Lee et al., 2010). Performance approach orientation, in turn, associates to the recognition of one's competence and standing out from others, whilst performance avoidance orientation is associated to the fear of seeming incompetent at work (Oliveira-Silva \& Porto, 2016).

The described dimensions compose the $2 \times 2$ model, such that all four orientation types relate to different antecedents and consequents (Elliot \& McGregor, 2001). According to studies by Tamir e Diener (2008), people can experiment meaning in life being oriented both by approach and avoidance dimensions, as long as the goals they pursue are meaningful to them. Studies indicate that people with approach orientation, in general, make better use of their competences (Dierendonck \& Gaast, 2013), besides that avoidance dimension does not show to be theoretically compatible with professional fulfillment as it concerns goal achievement, whilst avoidance involves withdrawing from mistakes in life (Oliveira-Silva, 2015). Tamir and Diener (2008) propose that if an individual is mainly approach motivated, the framing of a goal in terms of a final desired state increases the effort to reach that goal. Other studies point out that avoidance is linked to low goal progress perception, lower pleasure and fulfillment during goal striving and less subjective well-being (Elliot \& Sheldon, 1998).

Given the exposed and considering the presented evidence, it is questioned what happens with professional fulfillment when people prioritize developing competencies for themselves (mastery approach) or prioritize actions that aim the recognition of their competences and standing out from others (performance approach). Thus, the following hypotheses are considered:

H2: Mastery orientation approach dimension positively and significantly predicts professional fulfillment.

H3: Performance orientation approach dimension positively and significantly predicts professional fulfillment.

\section{METHODOLOGY}

This is quantitative research, with the differential intention of increasing the accuracy of investigations performed through the quantification of 
gathered information and its treatment through statistical techniques (Dalfovo, Lana, \& Silveira, 2008). The survey method was used, crosssectionally, aiming to produce quantitative descriptions of a population and using pre-defined instruments (Freitas, Oliveira, Saccol, \& Moscarola, 2000).

\subsection{Participants}

The study was conducted with 140 people within the labor market for at least six months, from both genders and aged over 18. Among the participants, $54.2 \%$ were women, $59.2 \%$ single, $72.1 \%$ under graduation and $55.7 \%$ less than 25 years old. Nonetheless, there were participants of various ages (aged 26 to $35=27.1 \%$; 36 to $55=15.7 \%$; over 55 years old $=0.7 \%$ ), typifying a reasonable distribution of sample when it comes to age group. In general, the participants classified their economic situation as regular $(52.8 \%)$ and stated that they earned up to three minimum wages $(77.8 \%)$.

\subsection{Instruments}

Professional fulfillment: Professional Fulfillment Scale by Oliveira-Silva (2015). The goal content part holds 16 items and four factors that address career goals content. The factors are Self-transcendence (four items), Selfenhancement (four items), Openness to change (four items) and Conservation (four items). For each item, answers ranged from one (no importance) to five (extremely important) in what refers to goal importance and from zero (none) to four (total) in what concerns to goal achievement. Multiplication of importance by achievement scores generates the professional fulfillment score, which ranges from zero to 20. Reliability indices (Alpha de Cronbach) from this part of the scale, for importance of subscale factors, ranging from 0.72 to 0.78 , in a way that the complete importance scale presents a 0.82 alpha. For the achievement subscale, though, reliability varies from 0.80 to 0.91 , being 0.92 the alpha for the complete scale. By considering the total score of professional fulfillment, alpha equals 0.92 .

Work centrality: Measure by Borges and Tamayo (2001) derived from the MOW group (1987) work. Here, work centrality is considered in two ways: Absolute Importance and Relative Importance. In a first way, it is assigned a value from one to ten to work importance in individual's life, and in a second way, work importance is compared to other spheres and domains 
of individual's life, such as family, leisure, community, and religion. By using this instrument, in addition to considering centrality from a comparative assessment in relation to other life spheres, a global score work centrality is calculated.

Achievement goal orientation: Translated and adapted to Brazil (OliveiraSilva \& Porto, 2016) from the instrument by Baranik, Barron, and Finney (2007), the Achievement Goal Orientation at Work Scale presents 18 items and four factors (mastery approach/avoidance and performance approach/ avoidance). The answers scale ranges from one (it does not look like me at all) to seven (it really looks like me). The reliability indices (Alpha de Cronbach) vary between 0.60 to 0.77 .

\subsection{Procedures}

Participants were invited to answer an online questionnaire (through the Survey Monkey platform) which presented not only socio-demographic questions but also assessed work centrality, professional fulfillment goals content and the kind of achievement goal orientation. The recruitment of people was made by convenience criteria and participants access availability, as well as by the snowball strategy since the questionnaire was available in social networks and sent to people who fit the sample characteristics.

All participants were informed about research aims and could only proceed through the questionnaire if they complied with the ICF (Informed Consent Form). No participant was identified and the research could be abandoned at any given time. In case of doubt, one could contact and consult the researcher via email.

\subsection{Data analysis}

Bivariate correlations and standard multiple regression analyses were used to analyze data and test the proposed hypotheses. Regression analysis seeks to determine the best predictors of criteria variables, however, it cannot identify causality, only the relation (or correlation) between variables (Abbad \& Torres, 2002). Relations between professional fulfillment factors, work centrality and kinds of goal orientations were observed. Descriptive and central tendency analyses were also performed, as a way to characterize the sample. Blank cases represented less than $5 \%$ of the total of the sample, being replaced by the average. Extreme cases were analyzed through Mahalanobis distance and did not represent more than $10 \%$ of the total 
sample, being kept due to their low occurrence, according to Tabachnick and Fidell (2013) orientations. Sample size (140 cases) was considered adequate to accomplish regression analyses since it attended Hair et al.'s (2009) criteria, which suggest 100 cases and/or a minimum reason of five cases per variable as an acceptable situation (considering nine variables, equivalent to the total of the analyzed factors). It also responded to Tabachnick and Fidell's (2013) criteria, which advocates that the sample size must be equal or above the result from the $50+8 \mathrm{~m}$ formula, being $\mathrm{m}$ the number of antecedent variables (five), resulting in this case in a minimum number of 90 cases.

\section{RESULTS}

As pointed out in Figure 6.1, the Pearson correlation coefficient revealed that there is a positive significant correlation $(r=0.223, p<0.01)$ between absolute importance of work (work centrality) and mastery approach (achievement goal orientation). Other variables considered in the hypotheses and which presented significant correlations $(p<0.01)$ were mastery approach and three factors of professional fulfillment: self-transcendence $(r=0.370)$, openness to change $(r=0.269)$ and conservation $(r=0.234)$. There were also positive significant correlations between the absolute importance of work (work centrality), conservation $(r=0.283)$ and selfenhancement $(r=0.289)$.

In what concerns to work centrality variable, it was only considered the absolute importance at work in regression equations, since relative importance of work did not present significant correlations with the other variables. As for professional fulfillment, only the data gathered from goal content measurement was analyzed, since hypotheses addressed only this dimension of fulfillment.

Results of standard multiple regression analyses indicated that work centrality (absolute importance of work factor) predicts significantly all professional fulfillment factors, being the relation with self-enhancement the strongest $\left(\mathrm{R}^{2}=0.084, \beta=0.289, p<0,001\right)$ and with openness to change, the weakest ( $\left.\mathrm{R}^{2}=0.027, \beta=0.165, p<0,001\right)$, according to what is shown in Figure 1. It is observed that work centrality positively and significantly predicts professional fulfillment factors. Thus, it is correct to state that hypothesis $\mathrm{H} 1$ was corroborated, although only one dimension of work centrality has been considered. 


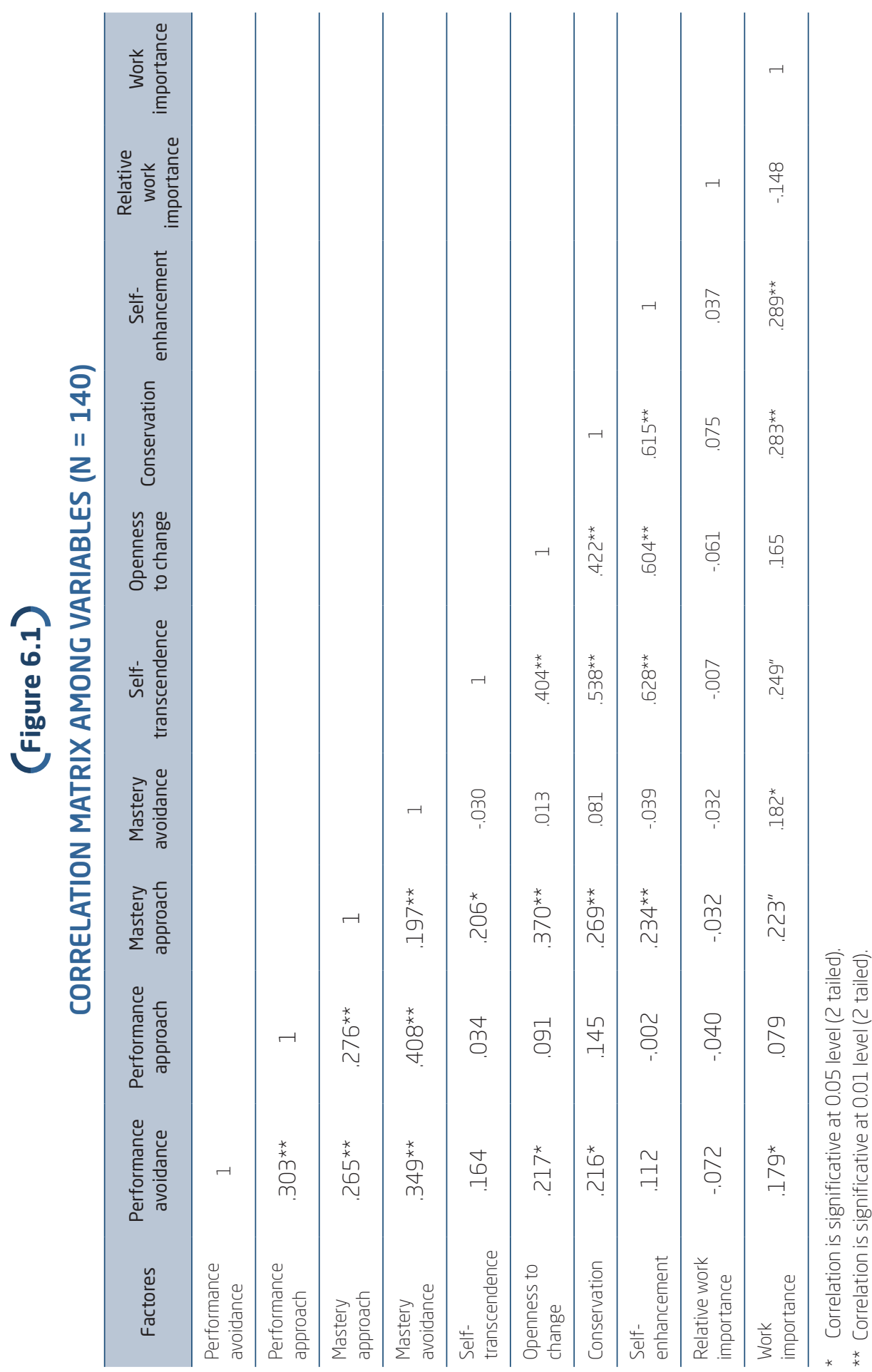




\section{(Figure 6.2)}

\section{REGRESSION COEFFICIENTS FOUND BETWEEN WORK CENTRALITY AND PROFESSIONAL FULFILLMENT}

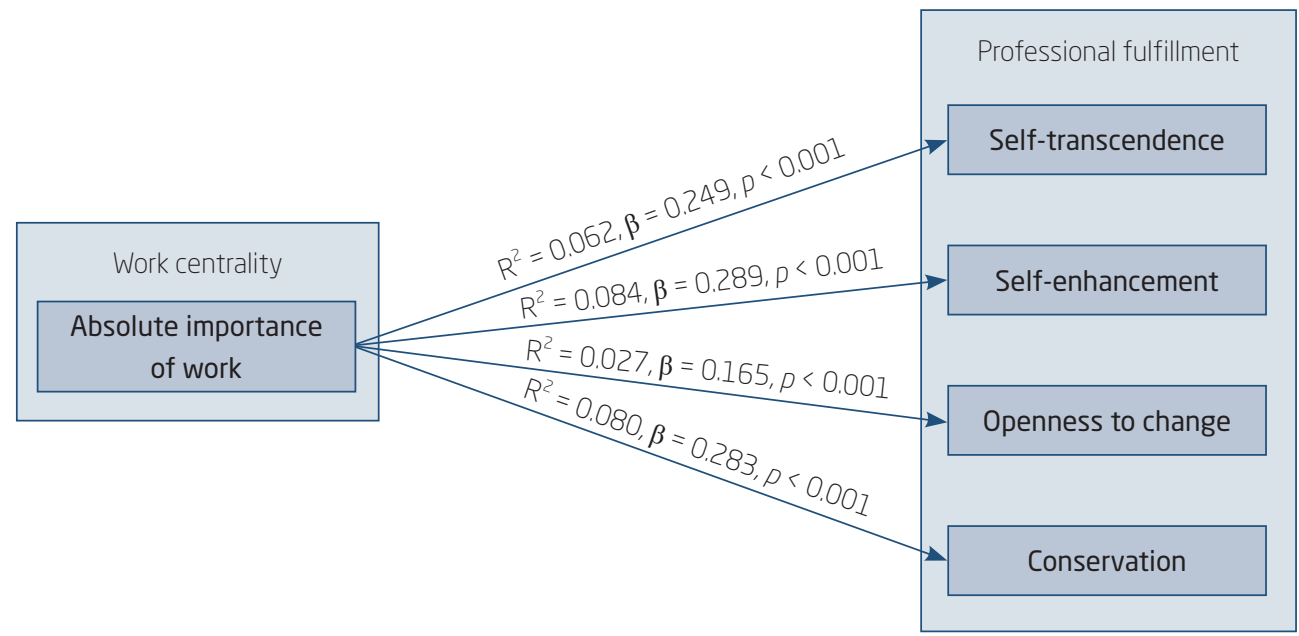

Source: Elaborated by the authors

In relation to goal orientation, regression results indicate that mastery approach predicts all professional fulfillment factors, being with openness to change its strongest relationship $(\beta=0.370, p<0.001)$ and with selftranscendence the weakest $(\beta=0.206, p<0.001)$, as seen in Figure 2 . Such findings corroborate hypothesis $\mathrm{H} 2$, albeit there was no significant relationship between performance approach and the four professional fulfillment factors, refuting hypothesis $\mathrm{H} 3$. 


\section{(Figure 6.3)}

\section{REGRESSION COEFFICIENTS BETWEEN MASTERY APPROACH GOAL ORIENTATION AND PROFESSIONAL FULFILLMENT}

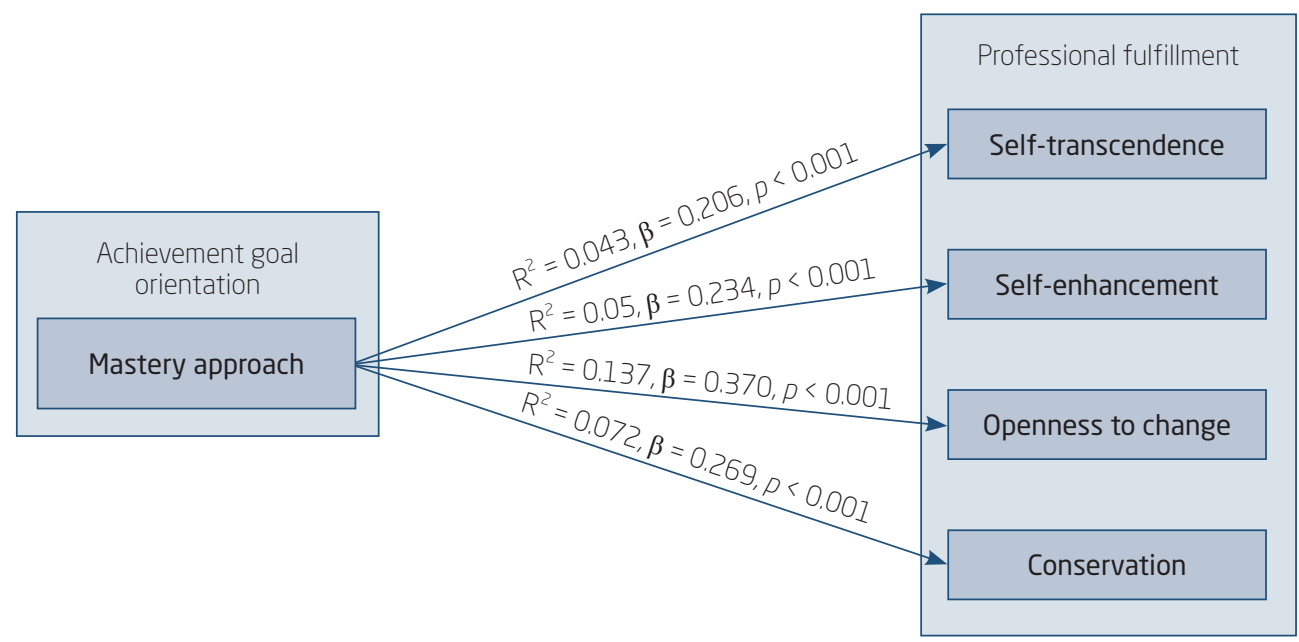

Source: Elaborated by the authors

\subsection{Discussion}

Considering the obtained results, it was observed that work centrality significantly predicts professional fulfillment in its four factors, confirming the first hypothesis (H1). Such finding points out that people who prioritize work and consider it to be central to their self-image (absolute work importance) to have more chances to attain what they value in a career, namely professional fulfillment, through any of the four possible goal contents. Such results dialogue with the ones from Bastos et al. (1995), according to which work allows status and prestige acquisition and takes on a self-expressive or intrinsic function when it is perceived as something interesting and that allows self-fulfillment. Therefore, performed researches corroborate that work has a central role in the organization of identity and in the contemporary subject construction (Morin, Tonelli, \& Pliopas, 2007), which is reinforced by the present research when it demonstrates that the more central work is in people's lives, the more probable they will fulfill themselves professionally.

The results found are also convergent with Kostek's (2012) metaanalysis, according to which work centrality is associated with greater 
satisfaction with life and work. Considering that professional fulfillment represents a positive assessment towards a career, the results found get closer to those from Aryee \& Luk (1996), which evidence that greater career satisfaction is positively predicted by work centrality. Finally, in a similar way, Sharma (2017) pointed out associations between work centrality, professional enhancement, and balance, which dialogue with the present research findings.

Although the results found are relatively intuitive, they are pioneers in the sense that they analyze the role of a classical variable in the working world, which is work centrality, with an innovative variable, which is professional fulfillment. On the other hand, the relative work centrality did not present significant correlations with professional fulfillment factors. This shows that, when work is compared to other important people's lives interests, such as leisure, family, and religion, professional fulfillment achievement is affected. A possible explanation for this is that professional fulfillment involves the achievement of the most valued goals in a career, demanding focus and targeting for the achievement of such goals, which may be crossed by other spheres of individuals' lives. Another possibility would be the presence of intervenient variables in this relationship or conditional factors. Lastly, it is also possible that the measurement of work centrality, through raking of life spheres, has caused dissonance that affected the participants' perception and, consequently, the correlation between the variables.

The second hypothesis proposes the existence of significant prediction between mastery approach goal orientation and professional fulfillment. The mastery approach explained the variation of all professional fulfillment factors, meeting, this way, the second hypothesis (H2). The obtained results reinforce the aforementioned premise that individuals who present mastery orientation when searching for their goals prioritize the development of new abilities, try to understand more deeply their work, enhance their competence and aim to reach a sense of mastery based on self-referenced standards (Ames, 1992). The fact that only mastery approach predicts professional fulfillment, which is verified by the refutation of $\mathrm{H} 3$, associates to previous results, which demonstrates that individuals who are mastery oriented gain more satisfaction and pleasure from their efforts to achieve their goals than performance oriented individuals (Harackiewicz, Barton, \& Elliot, 1998).

According to the study by Anderman and Wolters (2006), students who reported being mastery oriented persisted longer in academic tasks, were more committed to their respective work, reported low levels of incapacity 
related behaviors and chose to commit themselves to future optional tasks, such as enroll in an additional course after the conclusion of their current course. Most cited behaviors can be associated to achieve career goals successfully, by indicating persistence, commitment, effectiveness, and selfconfidence. It is possible to say then that mastery orientation can contribute to the improvement of work proficiency and to the effective persistence towards obstacles, what could benefit the achievement of important goals and the experience of professional fulfillment. Therefore, it is comprehended that the results evidenced that people who concern with really dominating a task and developing competencies have more chances to experiment professional fulfillment.

Still, with regard to $H 2$, the greater power of prediction $\left(R^{2}\right)$ found in results was between the independent variable and the openness to change factor $(13 \%)$. This result indicates that individuals who behave by focusing themselves on learning and developing competence that relates to their goals-mastery approach-tend to achieve a state of greater professional fulfillment through the search for innovative and challenging experiences in a career-openness to change. This premise is coherent because, by searching for challenge and innovation in a professional career, it can be said that new personal and professional competencies are developed by someone. This result converges to those found by Scholarios et al. (2008), which evidence that, in order to achieve career success, an attitude characterized by continuous learning, adaptation to new employment requirements, use of competences and capability to acquire new abilities is essential. Mastery approach orientation, in turn, presents a primary focus on learning, promoting a continuous improvement attitude and facilitates the treatment of mistakes and flaws that can occur throughout the career (Dierendonck \& Gaast, 2013). Finally, it is worth to mention that previous studies also emphasize how mastery orientation can help to deal with challenges at the work place (e.g. Janssen \& Van Yperen, 2004; Lee, Hui, Tinsley, \& Niu, 2006).

Still, in regard to goal orientation, the third hypothesis $(\mathrm{H} 3)$ involves the existence of a relationship between performance approach and professional fulfillment. Based on the performed analyses and the obtained results, this condition was refuted, considering that the mentioned orientation did not present significant relations to any of professional fulfillment factors. This result indicates, from the data gathered from the participant sample, that being recognized by competences and standing out from others do not contribute significantly to predict greater professional fulfillment. 
Similar results were found by Oliveira-Silva (2015), in which only mastery orientation related significantly to professional fulfillment. According to Elliot \& Dweck (2005), mastery goals are considered interpersonal, which means that mastery oriented individuals focus on developing competence and mastering tasks. Professional fulfillment is also considered an interpersonal variable since it is related to career goals that people value and pursue. Additionally, it is believed that achievement goal orientation creates different cognitive-perceptive structures for the way individuals approach, interpret and respond to fulfillment situations (Van Yperen \& Orehek, 2013). Performance and mastery orientation represent distinctive definitions of success, present different reasons to address and engage in fulfillment activities (Ames, 1992) and involve different ways of thinking about one's self, their tasks and their results, which can contribute to the comprehension of this study's results.

\section{FINAL CONSIDERATIONS}

The present study had as an overall aim to investigate how work centrality and goal orientation relates to professional fulfillment, being that aim achieved. According to Oliveira-Silva (2015), people have been taking more account for their professional choices, pointing out, this way, the pertinence of the current professional fulfillment concept and the investigation of factors that can contribute to its prevalence in people's careers. Moreover, work is considered an important life sphere and a ponderable element in individuals' identity definition (Bastos et al., 1995), which enhances the importance to study how work centrality can contribute to positive results in profession and work. The focus of the present study on goal theory should also be highlighted, indicating the necessity for more researches to demonstrate how goals can lead people to action to enhance their work and career lives. On an international level, the research field on goals already represents a considerable mature area, whilst in Brazil studies about the importance and role of goals in the human behavior are still limited (Oliveira-Silva, 2015).

A possible practical implication from this study is directed to career counselors, which can take into consideration the obtained results to help people understand which variables relate to professional fulfillment, contributing to the development of career projects based on the goals that each individual prioritizes to achieve. The findings in this study also offer valid information for managers and organizations in the sense that they 
must contribute to the development of organizational practices that can benefit a greater level of work satisfaction with the labor activity workers perform. Thus, people can perceive a greater degree of work importance, that is, a greater level work centrality, which has shown to be a professional fulfillment predictor according to the performed analyses. Faced with today's competitive market, it is important that workers are motivated, compromised and satisfied so that they can engender differentiated results.

Nonetheless, one of the limitations of the performed research was due to the fact that the sample is characterized as young and homogeneous, besides being relatively reduced, what probably influenced the power to explain results. It is perceived that both correlations and regression coefficients were low, such that the sample size could have been a problem. A second limitation involves the cross-sectional and correlational research design, which does not allow ensuring a casual relation between work centrality, goal orientation, and professional fulfillment. Another limitation is the relatively simple design of the research, analyzing only direct relations and not considering possible moderators or mediators for the relationship between work centrality and professional fulfillment, as well as between goal orientations and fulfillment. There is also the factor that only individual aspects are analyzed in relation to professional fulfillment, setting aside contextual variables.

Therefore, a suggestion for future researches is the investigation of other possible professional fulfillment antecedents, as well as the influence of contextual aspects that can contribute to it. Future studies involving the concept of professional fulfillment may likewise encompass people from different jobs, career stages and socio-economic contexts, also analyzing the moderation of other variables related to the labor context in the previously analyzed relations in this research, such as organizational climate and leadership, or career variables that are out of one's reach.

\section{CENTRALIDADE DO TRABALHO, METAS E REALIZAÇÃO PROFISSIONAL: INTERSECÇÕES ENTRE TRABALHO E CARREIRA}

\section{RESUMO}

Objetivo: O artigo é conduzido pela seguinte questão: como as narrativas de grupos de interesses contribuem para o diálogo entre a perspectiva da 
estratégia como prática e a teoria dos stakeholders?. O objetivo é analisar as mudanças, permanências e tensões nas narrativas dos stakeholders, vistas como práticas estratégicas, no contexto da mineração.

Originalidade/valor: A estratégia como uma prática social diz respeito às relações entre organizações, indivíduos e sociedade em busca de coexistência. Este estudo estabelece um diálogo entre a estratégia como prática social e uma perspectiva política dos stakeholders, considerando que interagem em redes, buscando a criação de valor a partir da mutualidade.

Design/metodologia/abordagem: A pesquisa de campo foi conduzida numa abordagem qualitativa e longitudinal. A coleta de dados utilizou técnicas de pesquisa documental em atas e vídeos de audiências públicas, pesquisa em jornal e realização de entrevistas.

Resultados: Os resultados mostram interações narrativas de seis grupos de interesse: organizações empreendedoras, poder público, educação, meio ambiente, moradores da área de implantação e setor produtivo. $\mathrm{O}$ resultado sugere um papel de relevância das tensões relacionais como elementos que restringem e possibilitam as mudanças e permanências, e evidenciam a natureza dinâmica das interações intra e intergrupos de stakeholders. O diálogo teórico proposto amplia o campo dos estudos da estratégia, em uma vertente pós-moderna, ao estabelecer um diálogo com uma vertente política da ação dos stakeholders, como alternativa a uma perspectiva funcionalista tradicional no campo.

\section{PALAVRAS-CHAVE}

Realização profissional. Carreira. Metas. Orientação para atingimento de metas. Centralidade do trabalho.

\section{REFERENCES}

Abbad, G., \& Torres, C. V. (2002). Regressão múltipla stepwise e hierárquica em Psicologia Organizacional: Aplicações, problemas e soluções. Estudos de Psicologia, 7(no. esp.), 19-29. doi:10.1590/S1413-294X20020003 00004

Ames, C. (1992). Classrooms: Goals, structures, and student motivation. Journal of Educational Psychology, 84(3), 261-271. 
Anderman, E. M., \& Wolters, C. A. (2006). Goals, values, and affect: Influences on student motivation. In P. Alexander, \& P. Winne (eds.), Handbook of educational psychology (pp. 369389). Mahwah, NJ: Lawrence Erlbaum Associates.

Ardichvili, A., \& Kuchinke, K. P. (2009). International perspectives on the meanings of work and working: Current research and theory. Advances in DevelopingHumanResources, 11 (2),155-167.doi:10.1177/1523422309333494

Aryee, S., \& Luk, V. (1996). Work and nonwork influences on the career satisfaction of dualearner couples. Journal of Vocational Behavior, 49, 38-52. doi:10.1006/jvbe.1996.0032

Baranik, L. E., Barron, K. E., \& Finney, S. J. (2007). Measuring goal orientation in a work domain: Construct validity evidence for the $2 \times 2$ framework. Educational and Psychological Measurement, 67(4), 697-718. doi:10.1177/ 0013164406292090

Bastos, A. V. B., Pinho, A. P. M, \& Costa, C. A. (1995). Significado do trabalho: Um estudo entre trabalhadores inseridos em organizações formais. Revista de Administração de Empresas, 35 (6), 20-29. doi:10.1590/S003475901995000600004

Bendassolli, P. F., Coelho-Lima, F., Araujo, R., \& Carvalho, P. (2015). The Brazilian scientific production on sense and meaning of work: Review of terminological use and current thematic classifications. Avances en Psicología Latinoamericana, 33(2), 203-221. doi:10.12804/ap133.02.2015.03

Borges, L. O. (1999). As concepções do trabalho: Um estudo de análise de conteúdo de dois periódicos de circulação nacional. Revista de Administração Contemporânea, 3(3), 81-108.

Borges, L. O., \& Tamayo, A. (2001). A estrutura cognitiva do significado do trabalho. Revista Psicologia Organizações e Trabalho, 1 (2), 11-44. Retrieved from http://pepsic.bvsalud.org/scielo.php? script=sci_arttext\&pid=S19 84-66572001000200002\&lng $=p t \& t \operatorname{lng}=p t$

Dalfovo, M. S., Lana, R. A., \& Silveira, A. (2008). Métodos quantitativos e qualitativos: Um resgate teórico. Revista Interdisciplinar Científica Aplicada, 2(4), 1-13. Retrieved from rica.unibes.com.br/index.php/rica/article/ download/243/234

Diefendorff, J. M., Brown, D. J., Kamin, A. M., Lord, R. G. (2002). Examining the roles of job involvement and work centrality in predicting organizational citizenship behaviors and job performance. Journal of Organizational Behavior, 23(1), 93-108. 
Dierendonck, D. V., \& Gaast, E. V. D. (2013). Goal orientation, academic competences and early career success. Career Development International, 18(7), 694-711.

Dubin, R. (1956). Industrial workers' worlds: A study of the "central life interests" of industrial workers. Social Problems, 3, 131-142. doi:10.2307/ 799133

Elliot, A. J. (2005). A conceptual history of the achievement goal construct. In A. J. Elliot, \& C. S. Dweck (Eds.), Handbook of competence and motivation (pp. 52-72). New York, NY: Guilford Press.

Elliot, A. J., \& McGregor, H. A. (2001). A 2x2 achievement goal framework. Journal of Personality and Social Psychology, 80(3), 501-519. Retrieved from https://www.ncbi.nlm.nih.gov/pubmed/11300582

Elliot, A. J. \& Sheldon, K. M. (1998). Avoidance personal goals and the personality-illness relationship. Journal of Personality and Social Psychology, 75(5), 1282-1299.

Freitas, H., Oliveira, M., Saccol, A. Z., \& Moscarola, J. (2000). O método de pesquisa survey. Revista de Administração, 35(3),105-112.

Greenhaus, J. H., Callanan, G. A., \& Godshalk, V. M. (2010). Career management (4th ed.). Thousand Oaks, CA: SAGE Publications.

Harackiewicz, J. M., Barton, K. E., \& Elliot, A. J. (1998). Rethinking achievement goals: When are they adaptive for college students and why? Educational Psychologist, 33(1), 1-21.

Janssen, O., \& Van Yperen, N. W. (2004). Employees' goal orientations, the quality of leader member exchange, and the outcomes of job performance and job satisfaction. Academy of Management Journal, 45(3), 368-384.

Kanungo, R. N. (1982). Measurement of job and work involvement. Journal of Applied Psychology, 67, 341-349. doi:10.1037/0021-9010.67.3.341

Kostek, J. (2012). Work centrality: A meta-analysis of the nomological network (Master's thesis). College of Bowling Green State University, Bowling Green, Ohio, EUA.

Kubo, S. H., \& Gouvêa, M. A. (2012). Análise de fatores associados ao significado do trabalho. Revista de Administração (São Paulo), 47(4), 540554. doi:10.5700/rausp1057

Kubo, S. H., Gouvêa, M. A., \& Mantovani, D. M. N. (2013). Dimensões do significado do trabalho e suas relações. Revista Pretexto, 14(3), 28-49. doi. org/10.21714/pretexto.v14i3.1408 
Lee, C., Hui, C., Tinsley, C. H., \& Niu., X. (2006). Goal orientations and performance: role of temporal norms. Journal of International Business Studies, 37(4), 484-98.

Lee, J. Q., McInerney, D. M., Liem, A. D., \& Ortiga Y. P. (2010). The relationship between future goals and achievement goal orientations: An intrinsic-extrinsic motivation perspective. Contemporary Educational Psychology, 35(4), 264-279. doi:10.1016/j.cedpsych.2010.04.004

Morin, E. (2004, August). Meaning of work in modern times. Paper presented at the 10th World Congress on Human Resources Management, Rio de Janeiro, RJ, Brazil.

Morin, E., Tonelli, M. J., \& Pliopas, A. L. V. (2007). O trabalho e seus sentidos. Psicologia e Sociedade, 19(1). doi:10.1590/S0102-71822007000 400008

MOW [Meaning of Working] International Research Team. (1987). The Meaning of Working. London, UK: Academic Press.

Oliveira-Silva, L. C. (2015). The importance of achieving what you value: A career goal framework of professional fulfillment (Doctoral dissertation). Universidade de Brasília, Brasília, DF, Brazil.

Oliveira-Silva, L. C., \& Porto, J. B. (2016). Escala de metas de realização no trabalho: Adaptação e evidências de validade. Avaliação Psicológica, 15(1), $1-10$.

Rios, M. C. (2015). Contratos psicológicos, centralidade do trabalho, autorregulação e estados emocionais: Um estudo com docentes do ensino superior (Doctoral dissertation). Universidade Federal da Bahia, Salvador, BA, Brazil.

Scholarios, D., Van der Heijden, B. I. J. M., Van der Schoot, E., Bozionelos, N., Epitropaki, O., Jedrzejowicz, P., et al. (2008). Employability and the psychological contract in European ICT sector SMEs. International Journal of Human Resource Management, 19(6), 1035-1055.

Schwartz, S. H., Cieciuch, J., Vecchione, M., Davidov, E., Fischer, R., Beierlein, C., \& Konty, M. (2012). Refining the theory of basic individual values. Journal of Personality and Social Psychology, 103, 663-688. doi:10.1037/ a0029393

Sharma, S. (2017). Work centrality and its relationship to work life balance. International Journal of Applied Business and Economic Research, 15(4), 249259. 
Tamir, M., \& Diener, E. (2008). Approach-avoidance goals and well-being: One size does not fit all. In A. J. Elliot (ed.), Handbook of approach and avoidance motivation (pp. 415-430). Mahwah, NJ: Erlbaum.

Tolfo, S. R., \& Piccinini, V. (2007). Sentidos e significados no trabalho:

Explorando conceito, variáveis e estudos empíricos brasileiros. Psicologia $\mathcal{E}$ Sociedade, 19(1), 38-46. doi:10.1590/S0102-71822007000400007

Van Yperen, N. W., \& Orehek, E. (2013). Achievement goals in the workplace: Conceptualization, prevalence, profiles, and outcomes. Journal of Economic Psychology, 38(C), 71-79.

Walia, P. (2011). Work life balance of working professionals: A study of IT and ITES industry. Patiala, India: Punjabi University.

Wrzesniewski, A. (2001). Finding positive meaning in work. In K. S. Cameron, J. E. Dutton, \& R. E. Quinn (eds.), Positive organizational scholarship: Foundations of a new discipline (pp. 296-308). San Francisco, CA: Berrett-Koehler.

\section{AUTHOR NOTES}

Aléxia O. R. Moura, Department of Organizational and Work Psychology, Universidade Federal de Uberlândia (UFU); \& Lígia C. O. Silva, Department of Social and Work Psychology, Universidade de Brasília (UnB).

Aléxia O. R. Moura is now Human Resources Analyst, Department of Organizational and Work Psychology, Universidade Federal de Uberlândia (UFU); \& Lígia C. O. Silva is now Adjunct Professor at Department of Organizational and Work Psychology at Universidade Federal de Uberlândia (UFU).

\section{EDITORIAL BOARD}

Editors-in-chief

Janette Brunstein

Silvio Popadiuk

Associated Editor Andrea Oltramari

Technical Support

Vitória Batista Santos Silva
EDITORIAL PRODUCTION

$\begin{array}{ll}\begin{array}{l}\text { Publishing Coordination } \\ \text { Irina Migliari }\end{array} & \begin{array}{l}\text { Layout Designer } \\ \text { Emap }\end{array} \\ \text { Copyeditor } & \text { Graphic Designer } \\ \text { Irina Migliari (English) } & \text { Libro } \\ \text { Carlos Villarruel (Portuguese) } & \\ \text { Language Editor } & \\ \text { Daniel de Almeida Leão (English) } \\ \text { Irina Migliari (Portuguese) }\end{array}$




\section{eRRATUM}

In the paper "Work centrality, goals and professional fulfillment: Intersections between work and career", published in Revista de Administração Mackenzie - RAM (Mackenzie Management Review), 20(1), eRAMG190087:

- At page 1, it should be read "LÍGIA C. OLIVEIRA-SILVA" instead of "LÍGIA C. O. SILVA".

- At page 1, it should be read in To cite this paper: "Moura, A. O. R., \& Oliveira-Silva, L. C. (2019)" instead of "Moura, A. O. R., \& Silva, L. C. O. (2019)".

- At page 25, it should be read in About the authors: "Aléxia O. R. Moura, Department of Organizational and Work Psychology, Universidade Federal de Uberlândia (UFU); \& Lígia C. Oliveira-Silva, Department of Social and Work Psychology, Universidade de Brasília (UnB). Aléxia O. R. Moura is now Human Resources Analyst at Sankhya Gestão de Negócios; \& Lígia C. Oliveira-Silva is now Adjunct Professor at Department of Organizational and Work Psychology at Universidade Federal de Uberlândia (UFU)." instead of "Aléxia O. R. Moura, Department of Organizational and Work Psychology, Universidade Federal de Uberlândia (UFU); \& Lígia C. O. Silva, Department of Social and Work Psychology, Universidade de Brasília (UnB). Aléxia O. R. Moura is now Human Resources Analyst, Department of Organizational and Work Psychology, Universidade Federal de Uberlândia (UFU); \& Lígia C. O. Silva is now Adjunct Professor at Department of Organizational and Work Psychology at Universidade Federal de Uberlândia (UFU)." 